\title{
Impact of Event Marketing on Tourists Inflow in the South-South Region of Nigeria
}

\author{
Nnenanya Doris, MSc, Chinedu N. Ogbuji, PhD, *Onuoha A. Onuoha, PhD \\ Department of Marketing, University of Port Harcourt, Port Harcourt, Nigeria \\ *ifony2005@yahoo.com
}

\begin{abstract}
The traditional media are giving way to event marketing as they are becoming less satisfying in passing message to the target audience. Borne of out of increased competitive pressure faced by business potentials, event marketing has been used as a pull strategy to reach current and potential customers. With its objectives of direct sales and image building, it incorporates elements from all promotional tools. The study, therefore, examined how event marketing could help to harness tourists inflow as a means of improving the dwindling Nigerian economy. To achieve this purpose. Data were collected from 327 respondents in the SouthSouth region of Nigeria, using a set of questionnaire. Testing the hypotheses using Spearman's rank correlation coefficient, the results showed that event marketing impacts positively on Nigeria's tourists inflow. The study concludes that event marketing could be another source of revenue for government. Recommendations were proffered for sustainable growth in the tourism sub-sector which will help in diversifying Nigeria's revenue base in the face of dwindling global oil price.
\end{abstract}

Keywords: Event Marketing, Tourism, Tourist Inflow.

\section{INTRODUCTION}

Presently, there has been increasing demand for tourism products in many developing countries. Tourism destinations are speedingly augmenting tourist attractions in various regions of the world. The jaw-dropping investments in hospitality, travel and tourism industry have become a quest for economic diversification for many countries (Alasoofi, 2009). The essence of event activities, whether public or private, commercial or charitable, celebratory or commemorative, is to gather people to participate in a memorable experience that would produce profitable result (Huseyin et al., 2011).

Nigeria, reputedly is endowed with cultures and heritage, landscapes and lives with potentials for tourist attractions for a sustainable economic development (Ayeni et.al, 2012). Cross River State became a trail blazer with Carnival Calabar, Obudu Cattle Ranch, Tinapa Business Resort, Aquavista, Agbokim waterfalls, Monolith sites and National park reserves. Also, the Rivers State Government joined the tourism event marketing with the advent of the CARNIRIV (Rivers Carnival) and the existing Port Harcourt Tourist Beach. Akwa Ibom has the Rafia village of Ikot-Ekpene. These profound events and attractions have received national and international publicity with large chunks of public funds infused into them. The governments of these states have claimed that the huge expenses on human and financial recourses on the events is for the purpose of diversifying the revenue base of their states. The implication of these huge investments on event marketing for tourist inflow in Nigeria, in general, and south south region, in particular, in the main thrust of this study.

\section{Statement of Problem}

Event marketing has been acknowledged as a means of enhancing mutual understanding and appreciation, and the provision of foundation upon which lasting socio economic situation are built around the world and within a country (Fascinating Nigeria, 2013). In view of above, huge financial, human and other resources are being invested in event product by the aforementioned state governments. In view of the following, this paper appraised the performance of event marketing in the areas of tourists attraction and boosting the economy of South-South region of Nigeria.

\section{RESEARCh QUESTIONS}

This study sought to answer the following questions:

1. What is the impact of event marketing on tourist inflow? 
2. How does tourism product impact on tourist inflow?

3. How does price of tourism product impact on tourist inflow?

4. How does place impact on tourist inflow?

5. How does promotion impact on tourist inflow?

\section{RESEARCH OBJECTIVES}

Based on the research questions, the following were the objectives of the study:

1. To evaluate the impact of event marketing on tourist inflow.

2. To analysis the impact of tourism product on tourist inflow.

3. To evaluate the impact of price of tourism product on tourist inflow.

4. To determine the impact of place on tourist inflow.

5. To determine the impact of promotion on tourist inflow.

\section{SigNificance OF THE STUdY}

Travel for recreation or leisure has become popular worldwide. International tourism has today become a major source of income for many countries (Aulia and Rastogi, 2015). As Nigeria has started making plans for diversification of the country's revenue base, the findings and recommendations of this study will serve as a catalyst in bringing tourists to Nigeria, thereby boosting the foreign exchange earning capacity of the country.

\section{LiTERATURE REVIEW}

Events provide opportunities for consumers to interact with service providers to get first-hand experience of the product (Leonard, 2002). Though distinct from the marketing communication mix, event marketing incorporates all the promotional tools (Huseyin et al., 2011) and captures people in a relaxed atmosphere (Vassilios, 2008, Teagen et. al., 2013). It provides companies with alternatives to the cluttered mass media (Vassilios, 2008) and narrow-casts campaign to the defined target audience through its medium of direct sales and image building (Huseyin et.al., 2011 and Raymond et-al, 2008). Wohfeil and Whelan (2006), Alexandru (2013) and Ukessay (2013) see event marketing as a pull strategy that assists in changing beliefs and behaviours of consumers towards products and services.

A number of researchers have suggested various dimensions of event marketing. Yashwant, (2011) suggests emotions, involvement, intellectual and spatial as the four dimensions of event marketing. Huseyin et. al., (2011) suggest a six-dimension event marketing: ticketing, transportation, human resources, budgeting, public relations and risk management. This study adopted Alexandru's (2013) $4 \mathrm{p}$ - dimension of sports marketing-Product, Price, Place, and promotion, as a 'road map' to ascertain tourist involvement. Thus, the dimensions of event marketing used in this study are tourism product, price, place and promotion.

\section{EVENT MARKETING AND TOURIST INFLOW}

Recently, there has been growing awareness of the importance of event marketing within the tourism industry. Marketing of tourism comes with various marketing challenges as the product involved is intangible, inseparable, variable and perishable (Lynn, 2005). Relatively, customer (tourist) gives value for money to services offered him. Likewise, event marketing aims at enhancing the event profile, meeting the needs of the event audience and generating revenue. It harnesses business-tobusiness relationship in the tourism supply chain and business-to-consumer relationship in terms of demand leading to a redefinition of organizational interactions and customer attention (Nigeria 360, 2002). Community- based tourism provides income generation opportunities (Usher et.al, 2010, Ajake et.al, 2012), rapid industrialization (Anjah, Rishi and Priyata, 2012), and innovation and change in an economy (Stephen et.al. 2006).

In tourism, the tourist is seen as a consumer of place or culture, as well as a purchaser of tourism products. Lately, tourists have become more knowledgeable, demanding and thoughtful in making choices concerning tourism products (Stephen et.al, 2010). Tourists have various motives for 
embarking on a trip; it could be sports, events and social forms of activities, religions, educational, medical, adventure and business. Moscow's Hierarchy of needs could be used to demonstrate the satisfaction of need in this context (Stephen et.al, 2010).

\section{Product And Tourists Inflow}

Product in event marketing, is the event itself, as well as the overall marketing effort (Alexandru, 2013). Lynn (2005) and Raj et.al.,(2010) outlined the physical aspect of event product as the event venue, quality of food, and quality of entertainment. These determine, to a large extent the category of target audience that would be attracted.

\section{Price And Tourists Inflow}

Price in event marketing represents the sacrifices (time, energy, money, and efforts) to be made or spent by the tourists in order to get the benefits of the event product. The determination of the price of the tourism product will impact on profit margins, supply, demand and marketing strategy (Purelybranded, 2013).

\section{Place and Tourists Inflow}

Place includes the various activities the event marketer undertakes to make the event product accessible and available to target customers. The physical location of the event arena could be encouraging or discouraging to intending or existing customers.

\section{Promotion AND Tourists Inflow}

Promotion includes all the activities the event marketer undertakes to communicate and promote the event product to the target market. It demands from the event marketer the ability to use appropriate promotional mix to ensure that the message of the event reaches and have the desired impact on the target market (Onuoha and Ogbuji, 2015).

Awareness of an upcoming event within a vicinity may not be timely disseminated. Globalization has aided in making business networks increasingly important and easy to communicate with the outside world (Lynn, 2005). Event marketers/vendors could pass information to event audience by means of various communication tools via online marketing/advert, cable TV commercials, and so on. The product (event), price of event participation, hospitality arrangements, geographical feature and location are of significant for tourists to take decision to attend an event or not.

On the basis of the above literature review, the following theoretical framework as shown in the figure below was developed.

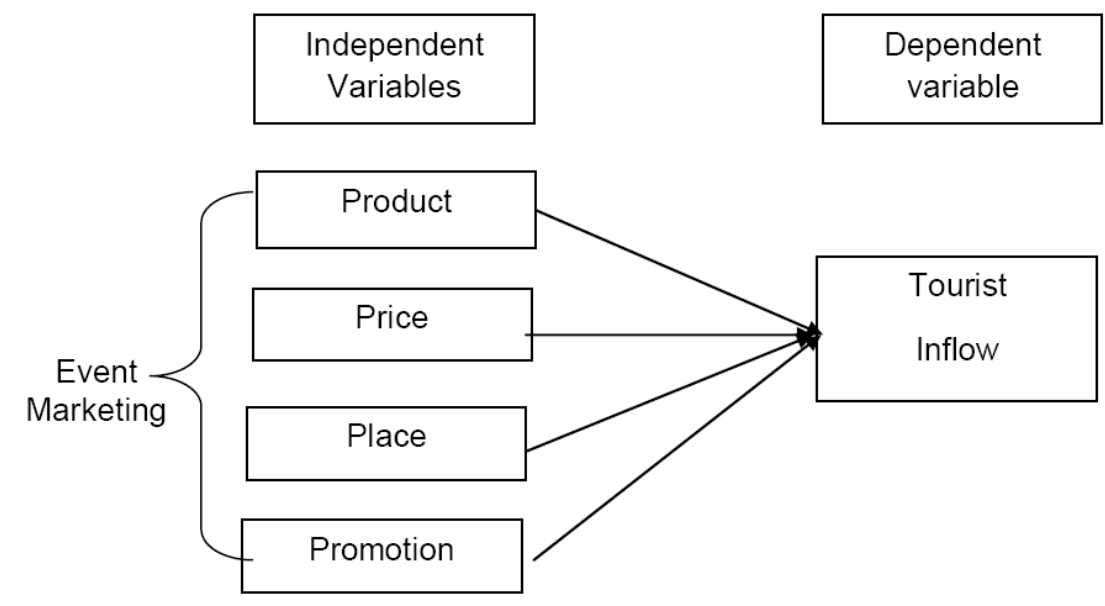

Fig1. Theoretical Framework for Event Marketing and Tourist Inflow.

Based on the theoretical framework above, the following hypotheses were developed for the study:

$\mathbf{H 0}_{1}$ : Tourism product does not have significant impact on tourist inflow in South-South region of Nigeria.

$\mathbf{H O}_{2}$ : Price of tourism product does not have significant impact on tourist inflow in South-South region of Nigeria. 
$\mathbf{H 0}_{3}$ : Place of tourism event does not have significant impact on tourist inflow in South-South region of Nigeria.

$\mathbf{H 0}_{4}$ : Promotion of tourism event product does not have significant impact on tourist inflow in South-South region of Nigeria.

\section{Materials AND Methods}

\subsection{Area of Study}

The study was carried out in the South-South region of Nigeria. It consists of six States- Rivers, Bayelsa, Akwa-Ibom, Cross River, Delta and Edo. The choice of the region is based on the fact that, it is the only region in the country where most states therein organize yearly carnivals that attract tourists worldwide.

\subsection{Instrument}

Primary data were generated using a set of questionnaire and face-to-face interview of sampled respondents from the region.

\subsection{Samples and Sampling Technique}

In this study, our population of interest included everyone resident in the South-South region of Nigeria. Based on the estimated 2012 census figures, the population of the region was $25,048,139$ (NPC, 2013).

Due to similarities in the elements of the population, a sample was drawn from the population. The Sample Size Determination Table developed by Krejcie and Morgan (1970), as adopted from Igwe (2012) was used to determine the sample size. From the Table, the sample size that corresponded with the population of 25, 048, 139 (a number within the range of 1,000,000 and above) is 384 . Thus, the sample size for this study is 384 . However, all elements that constituted the sample size were people who were available at the various spots where copies of the questionnaire were distributed or the interview conducted. This method of non-probability sampling is referred to as convenience sampling by Ezejelue et al (2008).

To find the impact of the independent variables on the dependent variable, Spearman's rank correlation coefficient, in SPSS (version 20.0) was used.

\section{ANALYSIS AND DISCUSSION}

Table1. Questionnaire Distribution and Retrieval

\begin{tabular}{|l|l|l|}
\hline Pattern & Number & Percent \\
\hline Not retrieved & 23 & 6 \\
\hline Retrieved but not used & 34 & 8.8 \\
\hline Retrieve and used & 327 & 85.2 \\
\hline Total & 384 & 100 \\
\hline
\end{tabular}

Source: Survey Data 2015

Table 1 above shows the distribution and return pattern of the questionnaire. Only the retrieved and correctly filled copies of the questionnaire (327) were used for analysis.

Table2. Reliability Analysis of Variables

\begin{tabular}{|l|l|l|}
\hline Variable & Items & Cronbach's Alpha \\
\hline Product & 8 & 0.944 \\
\hline Price & 8 & 0.838 \\
\hline Place & 8 & 0.777 \\
\hline Promotion & 5 & 0.719 \\
\hline Tourist Inflow & 5 & 0.740 \\
\hline
\end{tabular}

Source: SPSS (version 20.0) Output

Table 2 above shows the reliability of the five variables. There are 8 items of Product, 8 items of Price, 8 items of Place, 5 items of Promotion, and 5 items of Tourist Inflow. Their reliability values are, respectively, $0.944,0.838,0.777,0.719$, and 0.740 . In this study, the variables are interrelated and showed inter-consistency because value above 0.6 is acceptable. 
Impact of Event Marketing on Tourists Inflow in the South-South Region of Nigeria

Table3. Descriptive Statistics of Variables

\begin{tabular}{|l|l|l|l|}
\hline Variable & N & Mean & Std. Deviation \\
\hline Product & 327 & 3.92 & 1.2050 \\
\hline Price & 327 & 3.95 & 1.1635 \\
\hline Place & 327 & 4.00 & 1.1426 \\
\hline Promotion & 327 & 4.02 & 1.1736 \\
\hline Tourist Inflow & 327 & 4.06 & 1.1782 \\
\hline
\end{tabular}

Source: SPSS (version 20.0) Output

Table 3 above shows the Mean and Standard Deviation of the variables of the study in the sample of 327 respondents. While the Mean of the variables: Product, Price, Place, Promotion, and Tourist Inflow are 3.92, 3.95, 4.00, 4.02 and 4.06 respectively, the Standard Deviations are 1.2050, 1.1635, $1.1426,1.1736$, and 1.1782. All the Mean of the variables are greater than 3, signifying that event marketing has significant impact on tourist inflow in South-South region of Nigeria.

Table4. Result of Tourism Product and Tourist Inflow

\begin{tabular}{|ccl|l|l|}
\hline \multicolumn{5}{|c|}{ Correlations } \\
\hline Type & Variables 1 & Statistics & Product & Tourist Inflow \\
\hline Spearman's rho & Product & Correlation Coefficient & 1.000 & $.594^{* *}$ \\
& & & .000 \\
& Sig. (2-tailed) & 327 & 327 \\
\hline & $\mathrm{N}$ & $.594^{* *}$ & 1.000 \\
& Tourist Inflow & Correlation Coefficient & .000 & \\
& Sig. (2-tailed) & 327 & 327 \\
& $\mathrm{~N}$ & &
\end{tabular}

*** Correlation is significant at the 0.01 level (2-tailed).

Table 4 shows that the coefficient ( $\mathrm{r}$ ) and $\mathrm{p}$ values for tourism product are 0.594 and 0.000 , respectively, at 2.tailed test. Since the p value (0.000) is less than the alpha value (0.01), we accept the alternative hypothesis that tourism product has significant and positive impact on tourist inflow in South-South region of Nigeria.

Table5. Result of Tourism Price and Tourist Inflow

\begin{tabular}{|cll|l|l|}
\hline \multicolumn{4}{|c|}{ Correlations } \\
\hline Type & variables 1 & Statistics & Product & Tourist Inflow \\
\hline Spearman's rho & Price & Correlation Coefficient & 1.000 & $.684^{* *}$ \\
& & Sig. (2-tailed) & .000 \\
& $\mathrm{~N}$ & 327 & 327 \\
\hline & Courist Inflow & Correlation Coefficient & $.684^{* *}$ & 1.000 \\
& Sig. (2-tailed) & .000 & 327 \\
& $\mathrm{~N}$ & 327 & 327 \\
\hline
\end{tabular}

*** Correlation is significant at the 0.01 level (2-tailed).

Table 5 shows that the coefficient (r) and $\mathrm{p}$ values for price of tourism product are 0.684 and 0.000 , respectively, at 2-tailed test. Since the p value $(0.000)$ is less than the alpha value $(0.01)$, we accept the alternative hypothesis that price of tourism product has significant and positive impact on tourist inflow in South-South region of Nigeria.

Table6. Result of Tourism Place and Tourist Inflow

\begin{tabular}{|cll|l|l|}
\hline \multicolumn{4}{|c|}{ Correlations } \\
\hline Type & variables 1 & Statistics & Product & Tourist Inflow \\
\hline Spearman's rho & Place & Correlation Coefficient & 1.000 & $.662^{* *}$ \\
& & Sig. (2-tailed) & .000 \\
& & N & 327 & 327 \\
\hline & Tourist Inflow & Correlation Coefficient & $.662^{* *}$ & 1.000 \\
& & Sig. (2-tailed) & .000 & \\
& $\mathrm{~N}$ & 327 & 327 \\
\hline
\end{tabular}

*** Correlation is significant at the 0.01 level (2-tailed). 
Table 6 shows that the coefficient $(r)$ and $\mathrm{p}$ values for place of tourism are 0.684 and 0.000 , respectively, at 2-tailed test. Since the p value $(0.000)$ is less than the alpha value $(0.01)$, we accept the alternative hypothesis that place of tourism event has significant and positive impact on tourist inflow in South-South region of Nigeria.

Table7. Result of Tourism Promotion and Tourist Inflow

\begin{tabular}{|cl|l|l|}
\hline \multicolumn{3}{|c|}{ Correlations } \\
\hline Type variables 1 & Statistics & Product & Tourist Inflow \\
\hline Spearman's rho Promotion & Correlation Coefficient & 1.000 & $.886^{* *}$ \\
& Sig. (2-tailed) & & .000 \\
& $\mathrm{~N}$ & 327 & 327 \\
\hline & Correlation Coefficient & $.886^{* *}$ & 1.000 \\
& Sig. (2-tailed) & .000 & \\
& $\mathrm{~N}$ & 327 & 327 \\
\hline
\end{tabular}

*** Correlation is significant at the 0.01 level (2-tailed).

Table 7 shows that the coefficient (r) and $\mathrm{p}$ values for promotion of tourism are 0.684 and 0.000 , respectively, at 2-tailed test. Since the p value $(0.000)$ is less than the alpha value $(0.01)$, we accept the alternative hypothesis that promotion of tourism event has significant and positive impact on tourist inflow in South-South region of Nigeria.

\section{DisCUSSION OF FINDINGS}

Findings of this study highlight the impact of event marketing on tourist inflow. Our first hypothesis shows that tourism product has significant and positive impact on tourist inflow. The result is consistent with the views of Lynn (2005) and Raj et al. (2010) that the aspects of event, as a product, determine to a large extent the number of audience to be attracted. The second hypothesis reveals that price of the tourism product has significant and positive impact on tourist inflow. This result is supported by Purelybranded (2013) that there is significant relationship between price and demand for an event activity. The third hypothesis is proved as the result shows that place of tourism event has significant and positive impact on tourist inflow. This result is consistent with a study by Amalu et al. (2012) that event place influences and enhances the number of tourists for a particular event. The fourth hypothesis is also proved as the result reveals that promotion of tourism event has significant and positive impact on tourist inflow. This result is supported by Lynn (2005) that communication with the outside world about an event affects tourists participations positively.

\section{Conclusion}

The objective of this study was to investigate the impact of event marketing on tourist inflow in South-South region of Nigeria. This study considered four dimensions of event marketing-tourism product, price, place, and promotion. The dependent variable was tourist inflow and the independent variable was event marketing. Analysis was done through Spearman's correlation.

It is concluded from the analysis that event marketing has significant and positive impact on tourist inflow in South-South region of Nigeria. This means that there is steady increase in the number of tourists for the yearly carnivals in the States in the South-South region of Nigeria.

\section{RECOMMENDATIONS}

Based on the findings and conclusion of the study, the following are recommended.

1. Marketers of event should see the events to be marketed as a total package. The whole aspect of the event product, including the event venue, and quality of entertainment should be well packaged.

2. Event marketers should ensure that tourism events are well published so that consumers (tourists) will be aware of such upcoming events. For this purpose, Nigeria needs to promote its tourism across the countries, and make its impact on the global tourism map.

3. One of the objectives of event marketing is to increase tourist inflow in particular vicinity. In view of this, event marketing adverts should be designed and written in a manner that persuade individuals to purchase the event offered for sale to enhance the income of people in that vicinity as well as generate income for government. 
4. Hospitality toward guests is one of the things that tourists look forward to (Aulia and Rastogi, 2015). Thus, employees of hotels and residents of the host communities should ensure that tourists and guests are treated courteously, as this would increase the chance of repeat purchase from the tourists.

5. Government should create enabling environment for the development of tourism sector as a means of diversifying the revenue base of the country, especially in the face of dwindling revenue from oil, which has being the major revenue earner for the country for over four decades.

\section{REFERENCES}

Ahmad J., Somaye S. and Soraya S. (2011). Tourism and Economic Growth in Developing Countries: P-VAR Approach. Middle-East Journal of Scientific Research. 10 (1), 28-30.

Ajake A. 0. and Amalu T. E. (2012). The Relevance of Tourism on the Economic Development of Cross River State, Nigeria. Journal of Geography and Regional Planning, 5 (1),. 14-20.

Alexandru, L.M. (2013). Sport Marketing Mix Strategies. Cross-Cultural Management Journal, 15(2)

Amalu T. E. and Ajake A. 0. (2012). An Assessment of the Influence of Calabar Carnival on the Economy of the Residents of Calabar Metropolis, Cross Rivers State, Nigeria. Journal of Economics, (2),14-25.

Andy, M., Dan, F. and Daniela, Z., (2004) Outdoor and Experiential Learning: An Holistic and Creative Approach. Books.google.com.ng/books?isbn=056608628X

Anjan, K. B., Rishi, B.D and Priyata, C. (2012). Eco-Tourism Potentials at Tinsukia and Dibrugarh Districts of Upper Assam: Some Observations. Paripex Indian Journal of Research, 1 (11).

Anyadike N., Emeh I. and Ukah F. (2012). Entrepreneurship Development and Employment Generation in Nigeria: Problems and Prospects. Universal Journal of Education and General Studies, 1 (4), 88-102.

Aulia, S. and Rastogi, P. (2015). A Conceptual Paper on Heritage Tourism in Sultanate of Oman. International Journal on Managerial Studies and Research, 3 (11),99-101.

Ayeni, D. and Ebohon, 0. J; (2012). Exploring Sustainable Tourism in Nigeria for Development Growth. European Scientific Journal, 8, (20).

Asika, N. (2001) Research Methodology in the Behavioural Sciences. Lagos: Longman Nigeria PLC.

Bichaka F., Christian N. and Badassa T. (2007). The Impact of Tourism on Economic Growth and Development in Africa. Department of Economics and Finance Working Paper Series.

Carree, M. A. and Thurik, A. R. (2002). Impact of Entrepreneurship on Economic Growth. International Handbook of Entrepreneurship Research.

Carnival (2012) Rivers State in Destination Marketing Efforts. www.thisdaylive.com

Chai, L.G. (2009). A review of marketing Mix: 4ps or More? International Journal of Marketing Studies. 1(1).

Demand, M. (2013). How to Guide-fundamentals of event marketing. www.howto.com.

Dorothy R., and Rita N. (2012). Product Diversification for Sustainable Tourism Development: Exploring the Strengths and Challenges of Kisumu Region, Kenya. European Journal of Business and Social Sciences, 1(9).

Eja, I., Out J.E., Yaro M.A., and Inyang I.O. (2011). An Assessment of the Relevance of Christian Festivals in the development of Sustainable Hospitality in Calabar City. African Journal of Social Sciences, 1, ( 3), 1-9.

Ercan, E. (2013). Event Marketing in a Nut Shell. kandu-marketing.com.

Ezeyelue, A.C., Ogwo, E.O. and Nkamnese, A.D. (2008). Basic Principles in Managing Research Projects. and ed. Aba: Afritower Limited.

Frank, H. and Althoen, S.C. (1994). Statistics: Concepts and Applications. UK: Cambridge University Press.

Fubara, B.A. and Mguni, B.S. (1995). Research Methods in Management. London: Minerva Press.

Gliem, J. and Gliem R. (2003). Calculating, Interpreting and Reporting Cronbach's Alpha Reliability. scholarswork.iupui.edu

Gupta, C.B. and Gupta, V. (1998). An Introduction to Statistical Methods. New Delhi: Prentice House PVT Ltd. 
Huseyin, k., Mehpare, T. A., Metin, A. (2011). Special Event Management and Event Marketing: A Case Study of TKBL All Star 2011 in Turkey. International Journal of Management, 22 (1).

Hult, G.T.M., Snow, C.C. and Kandemir, D. (2003). The Role of Entrepreneurship in Building Cultural Competitiveness in Different Organizational Types. Journal of Management, 29 (3), 401-426.

Igwe, S.R. (2012). Factors Influencing University Lecturer's Patronage and Usage of GSM Services in South-South Nigeria. PhD Thesis, University of Port Harcourt, Port Harcourt, Nigeria.

Imikan A. M. and Ekpo, K. J. (2012). Infrastructural and Tourism Development in Nigeria: The Case Study of Rivers State. International Journal of Economic Development Research and Investment,. 3 ( 2).

Ja Teline (2010). What is the Role of an Entrepreneur in Economic Development. Available: http://www.preservearticles. Com

Jyostana S. (2007). Entrepreneur and Entrepreneurship. www.du.ac.in/fileadmin/DU/Academics/ course-materials.

Joseph, L., (2013) The 4Ps of Marketing. http://www.gamedev.net/page/resources/

Kayode, 0. (2012). Towards Economic Diversification and Sustainable Development. www.businessdayonline.com.

Kirzner, I. (1973). Competition and Entrepreneurship. Chicago: The University of Chicago Press.

Kotter P., Bowen J. I. and Makens C. J. (2010) Marketing for Hospitality and Tourism. 5th ed. New York: Pearson Educational.

Leonard, H. H. (2002). Event Marketing: How to Successfully Promote Events, Festivals, Conventions and Expositions. London: John Wiley and Sons, Inc.

Liao D. and Sohmen P., (2001). The Development of Modern Entrepreneurship in China. Stanford Journal of East Asian Affairs, 1(8).

Lynn, W. W. (2005). Event Management for Tourism, Cultural, Business and Sporting Events. Australia: Pearson Educational.

Marta P., Emilia V., Isabel N. and Elvira V. (2006). Entrepreneurial Development and Economic Growth. Global Journal of Human Social Sciences, 8 (6).

Mckercher B. (2003). Sustainable Tourism Development Guiding Principles for Planning and Management. Seminar on Sustainable Tourism Development, Kyrgystan.

Oladele, P.O, Akeke, N. I and Oladunjoye, D (2011). Entrepreneurship Development: A Panacea for Unemployment Reduction in Nigeria. Journal of Emerging Trends in Economics and Management Sciences, 2 (4).

Onuoha, A. O. and Ogbiji, C. N. (2005). Marketing Recipes for Popularizing and Creating Acceptance for Government Policies and Programmes in Nigeria. International Journal of Research in Business Studies and Management, 2 (10): 19-26.

Ontario, W., Caree, M.A. and Thurik, A.R (2002). The Impact of Entrepreneurship on Economic Growth. International Handbook of Entrepreneurship Research.

Prakash K. and Ricky S. (2010). Megamarketing on Event using Integrated Marketing Communications; The Success Story of TMH. Business Strategy Series, 11, (6), 372.

Randall G. (1998). Entrepreneurship and Economic Growth. Journal of Australian Economics, 1, (2), 45-62.

Raj, N. S. and Deepika U. (2010). Dimension of Indian Culture, Values and Event Marketing Implications- An Analysis. Asian. Journal of Tourism and Heritage. 3 (1).

Ranjan R. (2012). What are the Theories of Entrepreneurship. http://www.alloutdigital.com.

Sam, A., (2013). What is the Right Marketing Mix for Event Marketing. http://smallbusiness.chron. com.

Seetanah, B., Juwaheer, T. D., Lamport, M. J., Rojid, S., Sannassee, R. V. and Subadar A. U., (2011). Does Infrastructure Matter in Tourism Development? University of Mauritius Research Journal, $17,89-108$.

Selin, S. (1999). Developing a Typology, of Sustainable Tourism Partnership. Journal of Sustainable Tourism, 7 (3/4): 260-272. 
Shane, S. and Venkataraman, S. (2000). The promise of Entrepreneurship as a field of Research. The Academy of Management Review, 25 (1), 217-226.

Stephen J. and Joanne C. (2006) Tourism: A Modern Synthesis 2nd ed. Thomson Learning.

Sule, M. (2013) The Role of Entrepreneurship Education on Job Creation among Youths in Nigeria. Academic Journal of Interdisciplinary Studies, 2 (7).

Usher, L and Morais, D. B. (2010). Women's Human Agency and Self Determination in Guatemalan Tourism Development. http://cnr.ncsu.edu Hall and page.

Teagan, A., Jodie, C., and Steve, G. (2013). Branded Marketing Events: Facilitating Customer Brand and Engagement. $7^{\text {th }}$ International Conference of the Academy of Wine Business Research $(A W B R)$,

Una, O.O. (2007). Understanding Migrants' Remittances; Evidence from the U.S. - Nigeria Migration Survey, www.imi.ox.ac.uk/pdfs/researchprojects...migrations/una-osili-amai-op.

Vassilios (2008). Event Portfolio Planning and Management: A Holistic Approach. www.extension. lastate.edu.

Zoltan, A. (2006). How is Entrepreneurship Good for Economic Growth. www.mitpressjournals.org. 